\title{
1 A global hydrothermal reactor triggered prebiotic synthesis on Earth
}

2 Chiara Boschi ${ }^{1}$, Andrea Dini ${ }^{1, *}$, Gretchen L. Früh-Green ${ }^{2}$, Luca Caricchi ${ }^{3}$

1) Institute of Geosciences and Earth Resources - CNR, Via G. Moruzzi 1, 56124 Pisa, Italy

4 2) Department of Earth Sciences, ETH, Sonneggstrasse 5, 8092 Zurich, Switzerland

3) Department of Earth Sciences, University of Geneva, rue des Maraîchers 13, 1205, Geneva, Switzerland

*Corresponding author: andrea.dini@igg.cnr.it

9 Biosignatures in the rock record limit the time available for life to start on Earth to 600800 million years ${ }^{1}$ (4.5-3.7 Ga; Hadean-Archean). Whether the conditions for the synthesis of complex organic molecules were unique to this time or remain present today is unclear, but understanding these conditions is essential for the search of life on other planets. The outer portion of the Hadean Earth consisted of a thick mafic crust ${ }^{2}$ and the upper mantle from which the crust was extracted ${ }^{3}$. Here we show that the recycling of the Earth's initial crust to produce the first continental crust ${ }^{2,4-6}$, resulted in extreme thinning of the initial mafic crust allowing the interaction between ocean water and the upper mantle at a global scale. This global hydrothermal reactor was similar to the present-day active "Lost City Hydrothermal Field" , but extended on a planetary scale.

The geological record indicates that the interaction between $\mathrm{H}_{2} \mathrm{O}$ and olivine-rich rocks resulted in the production of 5-20 vol.\% brucite ${ }^{8-10}$, a key catalytic mineral for high temperature stabilisation, selection and phosphorylation of ribose ${ }^{11,12}$. The secular cooling of our planet ${ }^{2}$, the accretion of continental crust, and deposition of sediments progressively shut down the global reactor. These processes dramatically reduced the production of brucite and the probability of synthesizing prebiotic molecules. Our results suggest that the geodynamic evolution of planets should be considered when searching for life in the Universe. 
27 The period during which life originated on Earth is limited by the onset of habitability and the

28 appearance of the first documented lifeforms ${ }^{1}$. In the most favourable scenario, the Earth could

29 have been habitable as early as 4.5-4.3 Ga $\left(\right.$ Refs. $\left.^{3,13}\right)$. The first lifeforms are described in the

30 geological record at $3.7 \mathrm{Ga}\left(\right.$ Ref. $\left.{ }^{14}\right)$, which implies that pre-biotic molecules (PBM) must have

31 been available and possibly abundant in this $600-800$ million year time-window. Discounting

32 an external input of life by asteroids, hydrothermal systems in an oceanic environment ${ }^{7,15}$ or

33 on continents, driven by magmatic activity ${ }^{16}$ or by natural nuclear reactors ${ }^{17}$, are potential

34 niches for the synthesis of PBM. These systems provide the ingredients for the synthesis of the

35 building blocks of life in the early Earth: liquid water (oceans or continental pools), a variety

36 of gases (atmosphere and degassing) and minerals acting as catalysers ${ }^{18}$.

37 The discovery of submarine hydrothermal vents around Galapagos ${ }^{19}$ lead to the first hypothesis

38 for the synthesis of PBM in high-temperature mafic-hosted hydrothermal systems ${ }^{15}$. This idea

39 was later transferred to the low-temperature Lost City Hydrothermal Field (LCHF), an

40 ultramafic-hosted alkaline hydrothermal system discovered in 2000 near the slow-spreading

41 Mid-Atlantic Ridge ${ }^{7}$ (Fig. 1). Low temperature $\left(\sim 100^{\circ} \mathrm{C}\right)$ as well as reduced and alkaline

42 conditions ${ }^{7,20}$ are essential for the formose reaction, and have removed some of the theoretical

43 obstacles for a hydrothermal origin of life. Moreover, the production of a significant amount

44 of $\mathrm{H}_{2}$ and $\mathrm{CH}_{4}$ and formate vital for supporting life, were considered a significant improvement

45 with respect to the hypothesis of Ref. ${ }^{15}$. However, the formation of the building blocks of life

46 is per se insufficient and any hypothesis for the synthesis of PBM should include selection,

47 stabilization and phosphorylation of ribose in a natural environment ${ }^{21}$.

48 Here, instead of starting from a defined set of chemical reactions, we take a different approach

49 and assess which environments are potentially capable of synthesising $\mathrm{PBM}^{22}$ in the presence

50 of well-known catalytic minerals ${ }^{18}$, were available in the early Earth. We consider that the

51 probability of synthesizing PBM increases with the proportion of the planet in which all the 
52 essential requirements are met. Natural nuclear reactors would be punctual features as they

53 require high-grade $U$ ore deposits that are unlikely to be abundant in a chemically 54 undifferentiated Hadean crust $^{23}$. Continental hydrothermal systems are also punctual features 55 as the supply of heat is associated with volcanic systems and distributed along belts in a 56 discontinuous fashion. Hydrothermal systems associated with mid-ocean ridges occur along 57 linear features. Thus, all these environments would be active on a rather limited portion of the 58 planet. Looking back to the early Earth, after Theia's impact and the formation of the Moon at about $4.51 \mathrm{Ga}\left(\right.$ Ref. $\left.^{24}\right)$, a magma ocean was established that cooled and degassed ${ }^{13}$ to produce 60 the early atmosphere in a few million years ${ }^{13}$. Gravitational instability of the outermost portion of the solidified magma ocean (50 vol.\% olivine, 25 vol. \% cpx, 20 vol.\% opx, 5 vol. $\%$ plg) eventually resulted in its wholesale or incremental remova $1{ }^{13}$ accommodated by mantle ascent,

63 its partial melting and the construction of a thick $(20-40 \mathrm{~km})$ crust $^{2}$. The high degree of partial 64 melting that formed this initial crust left a residual, olivine-rich upper mantle ${ }^{2}$. The geological 65 investigation of Archean terrains suggest that the initial mafic/ultramafic crust was recycled 66 into the mantle ${ }^{2}$. During recycling, the hydrated mafic/ultramafic crust would partially melt 67 and a $10-30 \%\left(\right.$ Ref. $\left.^{25}\right)$ fraction of the removed material would have resurfaced as the early continental crust (Tonalite-Trondhjemite-Granodiorite; TTG) ${ }^{6,26,27}$. The newly formed crust was a fraction of the recycled mafic crust and the ocean floor must have been covered by much less sediments than today ${ }^{28}$. Thus, during this period of crustal regeneration, the potential exposure and interaction between the depleted upper mantle with water would have been more significant than at present. This, in turn, would have increased the potential for systems similar

73 to the LCHF to develop ${ }^{7,20}$.

74 At LCHF, the hydrothermal modification of the ultramafic mantle produces mainly serpentine 75 and magnetite and, where alkaline hydrothermal fluids discharged into the ocean, additional 76 brucite and carbonate (Fig. 1). These hydrothermal systems (LCHF, as well as hybrid 
77 Logatchev and Rainbow systems ${ }^{29,30}$ ) are extremely dynamic. Multistage serpentinization

78 generate a wide variety of niches characterised by specific $\mathrm{pH}$, redox potential, temperatures,

79 and activities of elements critical for prebiotic synthesis, distributed in space and changing with

80 time ${ }^{8-10,29,31-36}$. Moreover, abiotic hydrocarbons and carboxylic acids have been described in

81 hydrothermally altered mantle rocks of $\mathrm{LCHF}^{37}$. The following are some of the fundamental

82 reactions occurring in hydrothermal systems hosted by mantle lithologies ${ }^{31,38}$. The

83 serpentinization of olivine produces ferroan brucite, serpentine, and magnetite ${ }^{9,39}$ :

$84(\mathrm{Mg}, \mathrm{Fe})_{2} \mathrm{SiO}_{4}+\mathrm{H}_{2} \mathrm{O}=(\mathrm{Mg}, \mathrm{Fe})_{3} \mathrm{Si}_{2} \mathrm{O}_{5}(\mathrm{OH})_{4}+(\mathrm{Mg}, \mathrm{Fe})(\mathrm{OH})_{2}+\mathrm{Fe}_{3} \mathrm{O}_{4}+\mathrm{H}_{2}$

85 olivine water serpentine ferroan brucite magnetite

86 The formation of hydrogen is related to the amount of ferric iron in serpentine and to the moles

87 of magnetite produced (Eq. 1) ${ }^{10,31,38}$. Eventual increase in temperature (e.g. magma injection)

88 or changes in other thermodynamic variables (e.g. oxygen fugacity) destabilises ferroan brucite

89 leading to the massive precipitation of magnetite, associated with abundant production of

90 hydrogen:

$91(\mathrm{Mg}, \mathrm{Fe})(\mathrm{OH})_{2}+\mathrm{H}_{2} \mathrm{O}+\mathrm{SiO}_{2}=\mathrm{Mg}(\mathrm{OH})_{2}+\left(\mathrm{Mg}, \mathrm{Fe}_{3}\right)_{3} \mathrm{Si}_{2} \mathrm{O}_{5}(\mathrm{OH})_{4}+\mathrm{Fe}_{3} \mathrm{O}_{4}+\mathrm{H}_{2}+\mathrm{H}_{2} \mathrm{O}$

92 ferroan brucite brucite serpentine magnetite

93 Fundamentally, the reaction between $\mathrm{H}_{2}$ produced by hydrothermal circulation in ultramafic

94 rocks, and $\mathrm{CO}_{2}$ released from the mantle or magma degassing, produces $\mathrm{CH}_{4}$ as a final product

95 with methanediol as an intermediate reaction product (Eq. 3). The reaction of methanediol and

$96 \mathrm{H}_{2}$, produces formaldehyde (Eq. 4), the building block of life:

$97 \mathrm{CO}_{2}+4 \mathrm{H}_{2}=\mathrm{CH}_{4}+2 \mathrm{H}_{2} \mathrm{O}$ Sebatier-type reaction

$98 \mathrm{HCOOH}+\mathrm{H}_{2} \rightarrow \mathrm{CH}_{2}(\mathrm{OH})_{2} \rightarrow \mathrm{HCHO}+\mathrm{H}_{2} \mathrm{O}$ Formation of formaldehyde

99 Starting with formaldehyde and glycolaldehyde, under alkaline conditions and in the presence

100 of cation catalysts like $\mathrm{Mg}^{2+}$ and $\mathrm{Ca}^{2+}$, the formose reaction produces a variety of pentoses

101 (ribose, arabinose, xylose, lyxose, ribulose, xylulose ${ }^{40}$ ). Ribose, the essential constituent of 
RNA and DNA, is the least stable of the pentoses and rapidly decomposes to generate polymeric tar mixtures ${ }^{11}$. Selection, stabilization and accumulation of ribose, and its

104 phosphorylation to form RNA units, are key factors to unravel prebiotic chemistry and the 105 origin of life ${ }^{41}$. Borates and boric acid have been experimentally demonstrated to have this stabilizing effect on pentoses and to select ribose ${ }^{42,43}$. Moreover, phosphorus is necessary for phosphorylation, which is also assisted by borates and boric acid ${ }^{44}$. Because of the important role of borates, various authors have proposed different models for the accumulation of large quantities of these minerals ${ }^{45}$, which requires differentiated and evolved continental crust and subaerial ponds undergoing desiccation. The presence of such regions with high concentrations of $\mathrm{B}$ and $\mathrm{P}$ cannot be determined with any certainty as almost all of the Hadean rock record simply does not exist. Here we propose that prebiotic chemistry did not take place in borate deposits enriched in P but was mediated by the key catalyser brucite. This mineral adsorbs

114 large quantities of B and P (Refs. ${ }^{11,46-48}$ ), while being stable in an environment characterised

115 by high and variable $\mathrm{pH}$, a range of redox conditions, and participates in the synthesis of 116 formaldehyde. Additionally, the reactions involving ferroan brucite and brucite modulate the 117 release of $\mathrm{H}_{2}$ and the availability of $\mathrm{Mg}^{2+}$. These elements and conditions are all required to select ribose from the other pentoses, stabilise it to relatively high temperatures and facilitate phosphorylation which is key for the transition to self-replicating macro-molecules ${ }^{11,48}$ (Eq. 2). While other potential catalysers could have been stabilised by the interaction between mafic crust and ocean water, their abundance would have been extremely limited with respect to the amount of brucite produced by interaction between water and mantle lithologies (Fig. 2). This is especially true for the olivine-rich mantle produced by high degrees of melting during the

124 production of the early mafic crust.

125 We propose that during the period of crust regeneration in the Hadean-Archean, a global 126 ultramafic reactor was active, producing copious amounts of brucite and thus PBM. 
127 Fundamental for the plausibility of a global ultramafic reactor is the assumption that the

128 oceanic crust was sufficiently thin to allow oceanic water to penetrate into the upper mantle

129 and trigger the formation of brucite. To estimate the evolution of crustal thickness in time, once

130 clement conditions were established on Earth (4.5-4.3 Ga; Refs. $\left.{ }^{13,49}\right)$, we performed mass

131 balance calculations using a Monte Carlo approach (100'000 repetitions). We rely on

132 geological ${ }^{2,50}$ and experimental petrological ${ }^{25}$ constraints to define a plausible range of the

133 parameters (Methods). The results show that due to recycling the Hadean crust progressively

134 thins and for the largest number of simulations, reaches a minimum after around 200-300 Myrs

135 from the onset of Hadean crust recycling (Fig. 3b; Note that for simplicity of comparison in

136 the calculations we have always assumed that recycling started at $4.51 \mathrm{Ga}$ ). At this time the

137 thickness of the mafic crust obtained from the largest number of simulations is lower than 2000

$138 \mathrm{~m}$, which is significantly thinner than today's average oceanic crust $\left(6000 \mathrm{~m}\right.$; Ref. ${ }^{30}$; Fig. $\left.3 \mathrm{c}\right)$.

139 This is in agreement with the decreasing thickness of the oceanic crust observed when large

140 portions of the Earth crust disaggregate increasing the cooling rate of the mantle ${ }^{51}$. It should be

141 noted that because we do not consider recycling of newly formed mafic and TTG-type crust,

142 all thicknesses presented are maximum estimates. Additionally, the rate of production of new

143 crust was likely heterogeneous, as also shown by numerical modelling ${ }^{4,5}$. Thus, our mass

144 balance suggests that at around 4.5-4 Ga, large portions of the upper mantle were either covered

145 by a thin oceanic crust or exposed on the ocean floor. This would have allowed the interaction

146 between ocean water and the upper mantle ${ }^{52}$ at a global scale, triggering the production of

147 substantial amounts of brucite both above and below sea level (Fig. 1) and boosting the

148 production of PBM. As these conditions were never reproduced on Earth, any process that

149 would have isolated the mantle from the interaction with water within this optimal time window

150 might have left the Earth a lifeless planet. At present, the upper mantle is exposed to the

151 interaction with water only in very limited portions of our planet $(0.29 \%$ of the surface; 
Methods). Hence, the probability of todays' Earth to synthesis PBM is vanishingly small in comparison to the Hadean-Archean. As a result of the intimate relationship between life and

154 the evolution of planets, the rate and sequence of geological processes, as well as the presence 155 of catalytic minerals should be considered when searching for life in the Universe.

\section{Methods}

We consider that the recycling of the mafic/ultramafic crust Hadean Earth's crust results in the production of TTGs ${ }^{2,6,53}$. We make no inference on the actual geodynamic process responsible

160 for crustal recycling. We consider that the degree of partial melting of a mafic/ultramafic 161 protolith required to produce TTGs varies between 0.1 and $0.3\left(\mathrm{mf} ;\right.$ Ref. $\left.^{25}\right)$. Estimates for the initial thickness of the mafic/ultramafic crust in the Hadean $\left(T h_{i H}\right)$ vary between 20 and $40 \mathrm{~km}$ as inferred from non-arc basalts and cratonic peridotite residues ${ }^{2}$. Thus, we selected this range

164 for our calculations. We consider to end member scenarios for the growth of the mass of 165 continental crust over time $\left(M_{c}(t)\right)$ from Ref. ${ }^{54}$ (Fig. 3a):

166

$M_{c}(t)=\frac{M_{c}\left(t_{p}\right)}{1-e^{-k g\left(t_{p}-t_{s}\right)}}\left(1-e^{-k_{g}\left(t-t_{s}\right)}\right)$

167 Where $M_{c}\left(t_{p}\right)$ is the current mass of continental crust, $t_{s}$ and $t_{p}$ correspond to time at the onset 168 of growth of continental crust and the present time measured from the beginning of the solar 169 system, respectively, $k_{g}$ is a growth constant and $t$ is time. Considering a radius of the Earth of $1706371 \mathrm{~km}$ and a density of the continental crust $\left(\rho_{c c}\right)$ of $2700 \mathrm{~kg} / \mathrm{m}^{3}$, we can convert $M_{c}(t)$ into

171 the evolution of continental crust thickness $\left(T h_{c c}\right)$ over time and perform our mass balance 172 calculations in 1D. We assume a density of the mafic/ultramafic Hadean crust of $2900 \mathrm{~kg} / \mathrm{m}^{3}$ $173\left(\rho_{H}\right.$; different densities do not affect significantly our calculations) and calculate the temporal 174 evolution of the thickness of the mafic/ultramafic crust $\left(T h_{H}\right.$, which is recycled to produce 175 continental crust) as: 
$176 T h_{H}=T h_{i H}-\frac{T h_{c c}}{m f} \frac{\rho_{c c}}{\rho_{H}}$

177 Additionally, we consider that while Hadean mafic and ultramafic crust was recycled to 178 produce continental crust, the partial melting of the mantle also produced also new mafic crust.

179 To estimate the thickness of new mafic crust $\left(T h_{m}\right)$ we use the Archean geological record. The 180 fraction of volcanic rocks in Greenstone belts $\left(f v_{G b}\right)$ varies between 0.2 and 0.8 , of which a

181 fraction of 0.5 to 0.9 is represented by mafic rocks ${ }^{2}\left(f_{m}\right)$. We consider that the same proportions 182 also apply to intrusive rocks (intrusive mafic=gabbros; $f i_{g}$ ), but the repartition does not change 183 the results of our calculations. The thickness of mafic rocks is:

$184 T h_{m}=T h_{c c} f v_{G b} f_{m}+T h_{c c}\left(1-f v_{G b}\right) f i_{g}$

185 To compare the amount of upper mantle rocks potentially interacting with seawater in the

186 Hadean and nowadays, we estimate the mantle presently exposed on the seafloor. Mantlederived ultramafic rocks occur along the axial valley of slow spreading ridges (spreading rates $<4 \mathrm{~cm} / \mathrm{yr}$ ), most commonly near axial discontinuities. Ref. ${ }^{33}$ estimated that mantle lithologies represent about $23 \%$ of the newly formed oceanic crust along slow spreading ridges. Moving off-axis $(>100 \mathrm{~km})$, the oceanic crust is rapidly blanketed by sediments ${ }^{28}$ hampering the interaction between seawater and mantle rocks. Considering the total length of slow spreading ridges $(31880 \mathrm{~km}), 100 \mathrm{~km}$ distance on each side of the ridge, and the percentage of mantle rocks exposed at the seafloor (23\%), the ultramafic reactive surface represents $0.29 \%$ of the total Earth's surface.

\section{References}

197 1. Pearce, B. K. D., Tupper, A. S., Pudritz, R. E. \& Higgs, P. G. Constraining the Time Interval for the 198 Origin of Life on Earth. Astrobiology 18, 343-364 (2018).

1992 2. Herzberg, C. \& Rudnick, R. Formation of cratonic lithosphere: An integrated thermal and petrological $200 \quad$ model. Lithos 149, 4-15 (2012).

201 3. O’Neill, C. \& Debaille, V. The evolution of Hadean-Eoarchaean geodynamics. Earth Planet. Sci. Lett. 
406, 49-58 (2014).

203 4. Sizova, E., Gerya, T., Stüwe, K. \& Brown, M. Generation of felsic crust in the Archean: A geodynamic modeling perspective. Precambrian Res. 271, 198-224 (2015).

205 5. Capitanio, F. A., Nebel, O., Cawood, P. A., Weinberg, R. F. \& Chowdhury, P. Reconciling thermal regimes and tectonics of the early Earth. Geology 47, 923-927 (2019).

207 6. Moyen, J.-F. \& Martin, H. Forty years of TTG research. Lithos 148, 312-336 (2012).

208 7. Kelley, D. S. et al. An off-axis hydrothermal vent field near the Mid-Atlantic Ridge at $30^{\circ}$ N. Nature 412, 145-149 (2001).

8. Templeton, A. S. \& Ellison, E. T. Formation and loss of metastable brucite: does Fe(II)-bearing brucite support microbial activity in serpentinizing ecosystems? Philos. Trans. R. Soc. A Math. Phys. Eng. Sci. 378, 20180423 (2020).

10. Klein, F., Humphris, S. E. \& Bach, W. Brucite formation and dissolution in oceanic serpentinite. Geochemical Perspect. Lett. 1-5 (2020). doi:10.7185/geochemlet.2035

11. Holm, N. G., Dumont, M., Ivarsson, M. \& Konn, C. Alkaline fluid circulation in ultramafic rocks and formation of nucleotide constituents: a hypothesis. Geochem. Trans. 7, 7 (2006).

12. Estrada, C. F. et al. Aspartate transformation at $200^{\circ} \mathrm{C}$ with brucite $[\mathrm{Mg}(\mathrm{OH}) 2], \mathrm{NH} 3$, and $\mathrm{H} 2$ : Implications for prebiotic molecules in hydrothermal systems. Chem. Geol. 457, 162-172 (2017).

13. Elkins-Tanton, L. T. Linked magma ocean solidification and atmospheric growth for Earth and Mars. Earth Planet. Sci. Lett. 271, 181-191 (2008).

14. Dodd, M. S. et al. Evidence for early life in Earth's oldest hydrothermal vent precipitates. Nature 543, 60-64 (2017).

15. Corliss, J. B., Baross, J. A. \& Hoffman, S. E. An hypothesis concerning the relationship between submarine hot springs and the origin of life on earth. Oceanol. Acta 1980, 59-69 (1981).

16. Mulkidjanian, A. Y., Bychkov, A. Y., Dibrova, D. V., Galperin, M. Y. \& Koonin, E. V. Open Questions on the Origin of Life at Anoxic Geothermal Fields. Orig. Life Evol. Biosph. 42, 507-516 (2012).

17. Ebisuzaki, T. \& Maruyama, S. Nuclear geyser model of the origin of life: Driving force to promote the synthesis of building blocks of life. Geosci. Front. 8, 275-298 (2017).

18. Hazen, R. M. Chance, necessity and the origins of life: a physical sciences perspective. Philos. Trans. R. 
Soc. A Math. Phys. Eng. Sci. 375, 20160353 (2017).

233 19. Corliss, J. B. et al. Submarine Thermal Springs on the Galápagos Rift. Science (80-. ). 203, 1073-1083 (1979).

20. Früh-Green, G. L. et al. 30,000 Years of Hydrothermal Vent Field. Science (80-. ). 301, 495-498 (2003).

21. Sasselov, D. D., Grotzinger, J. P. \& Sutherland, J. D. The origin of life as a planetary phenomenon. Sci. $A d v .6,1-10(2020)$.

22. Lang, S. Q. \& Brazelton, W. J. Habitability of the marine serpentinite subsurface: a case study of the Lost City hydrothermal field. Philos. Trans. R. Soc. A Math. Phys. Eng. Sci. 378, 20180429 (2020).

23. Smit, M. A. \& Mezger, K. Earth's early O2 cycle suppressed by primitive continents. Nat. Geosci. 10, 788-792 (2017).

243 24. Barboni, M. et al. Early formation of the Moon 4.51 billion years ago. Sci. Adv. 3, 1-9 (2017).

244 25. Moyen, J.-F. \& Stevens, G. Experimental constraints on TTG petrogenesis: Implications for Archean geodynamics. in Geophysical Monograph Series 164, 149-175 (2006).

26. Dhuime, B., Wuestefeld, A. \& Hawkesworth, C. J. Emergence of modern continental crust about 3 billion years ago. Nat. Geosci. 8, 552-555 (2015).

27. Korenaga, J. Estimating the formation age distribution of continental crust by unmixing zircon ages. Earth Planet. Sci. Lett. 482, 388-395 (2018).

28. Ewing, M., Carpenter, G., Windisch, C. \& Ewin, J. Sediment Distribution in the Oceans: The Atlantic. Geol. Soc. Am. Bull. 84, 71 (1973).

29. Charlou, J. L. et al. High production and fluxes of $\mathrm{H} 2$ and $\mathrm{CH} 4$ and evidence of abiotic hydrocarbon synthesis by serpentinization in ultramafic-hosted hydrothermal systems on the Mid-Atlantic Ridge. in Diversity of Hydrothermal Systems on Slow Spreading Ocean Ridges 265-296 (2010). doi:10.1029/2008GM000752

30. Staudigel, H. Hydrothermal Alteration Processes in the Oceanic Crust. in Treatise on geochemistry (2003).

258 31. Bach, W., Garrido, C. J., Paulick, H., Harvey, J. \& Rosner, M. Seawater-peridotite interactions: First insights from ODP Leg 209, MAR 15². Geochemistry, Geophys. Geosystems 5, n/a-n/a (2004). 
data. Geochim. Cosmochim. Acta 72, 1801-1823 (2008).

263 33. Cannat, M., Fontaine, F. \& Escartín, J. Serpentinization and associated hydrogen and methane fluxes at slow spreading ridges. in Diversity of Hydrothermal Systems on Slow Spreading Ocean Ridges 241-264 (2010). doi:10.1029/2008GM000760

34. Malvoisin, B. Mass transfer in the oceanic lithosphere: Serpentinization is not isochemical. Earth Planet. Sci. Lett. 430, 75-85 (2015).

35. Bach, W., Peucker-Ehrenbrink, B., Hart, S. R. \& Blusztajn, J. S. Geochemistry of hydrothermally altered oceanic crust: DSDP/ODP Hole 504B - Implications for seawater-crust exchange budgets and Sr- and Pb-isotopic evolution of the mantle. Geochemistry, Geophys. Geosystems 4, 40-55 (2003).

36. Hildebrand, R. S., Hoffman, P. F., Housh, T. \& Bowring, S. A. The nature of volcano-plutonic relations and the shapes of epizonal plutons of continental arcs as revealed in the Great Bear magmatic zone, northwestern Canada. Geosphere 6, 812-839 (2010).

37. Ménez, B. et al. Abiotic synthesis of amino acids in the recesses of the oceanic lithosphere. Nature 564, 59-63 (2018).

38. Evans, B. W. Lizardite versus antigorite serpentinite: Magnetite, hydrogen, and life(?). Geology 38, 879-882 (2010).

39. Boschi, C., Früh-Green, G. L., Delacour, A., Karson, J. A. \& Kelley, D. S. Mass transfer and fluid flow during detachment faulting and development of an oceanic core complex, Atlantis Massif (MAR $30^{\circ} \mathrm{N}$ ). Geochemistry, Geophys. Geosystems 7, n/a-n/a (2006).

40. Joyce, G. F. RNA evolution and the origins of life. Nature 338, 217-224 (1989).

41. Scorei, R. Is Boron a Prebiotic Element? A Mini-review of the Essentiality of Boron for the Appearance of Life on Earth. Orig. Life Evol. Biosph. 42, 3-17 (2012).

42. Furukawa, Y., Horiuchi, M. \& Kakegawa, T. Selective Stabilization of Ribose by Borate. Orig. Life Evol. Biosph. 43, 353-361 (2013).

286 43. Ricardo, A. Borate Minerals Stabilize Ribose. Science (80-. ). 303, 196-196 (2004).

287 44. Furukawa, Y. \& Kakegawa, T. Borate and the Origin of RNA: A Model for the Precursors to Life. Elements 13, 261-265 (2017).

45. Grew, E. S., Bada, J. L. \& Hazen, R. M. Borate Minerals and Origin of the RNA World. Orig. Life Evol. Biosph. 41, 307-316 (2011). 
artificial seawater. Clim. Past 7, 693-706 (2011).

293 47. Prodromou, K. P. Boron adsorption on freshly prepared $\mathrm{Mg}(\mathrm{OH}) 2$. Neues Jahrb. für Mineral. Monatshefte 2004, 221-227 (2004).

48. Karl, D. M. \& Tien, G. MAGIC: A sensitive and precise method for measuring dissolved phosphorus in aquatic environments. Limnol. Oceanogr. 37, 105-116 (1992).

49. Sleep, N. H. Geological and Geochemical Constraints on the Origin and Evolution of Life. Astrobiology 18, 1199-1219 (2018).

50. Taylor, S. R. \& McClennan, S. M. The continental crust: its composition and evolution. (Blackwell Scientific Publications, 1985).

301

51. Van Avendonk, H. J. A., Davis, J. K., Harding, J. L. \& Lawver, L. A. Decrease in oceanic crustal thickness since the breakup of Pangaea. Nat. Geosci. 10, 58-61 (2017).

52. Zwan, F. M., Chadwick, J. P. \& Troll, V. R. Textural history of recent basaltic-andesites and plutonic inclusions from Merapi volcano. Contrib. to Mineral. Petrol. 166, 43-63 (2013).

53. Sizova, E., Gerya, T., BROWN, M. \& Perchuk, L. L. ScienceDirect.com - Lithos - Subduction styles in the Precambrian: Insight from numerical experiments. LITHOS (2010).

307 54. Rosas, J. C. \& Korenaga, J. Rapid crustal growth and efficient crustal recycling in the early Earth: Implications for Hadean and Archean geodynamics. Earth Planet. Sci. Lett. 494, $42-49$ (2018).

55. Alt, C., Honnorez, J., Laverne, C. \& Emmermann, R. Hydrothermal alteration of a $1 \mathrm{~km}$ section through the upper oceanic crust. DSDP Hole 504B: Mineralogy, chemistry and evolution of seawater-basalt interactions. J. Geophys. 91, 309-335 (1986). 


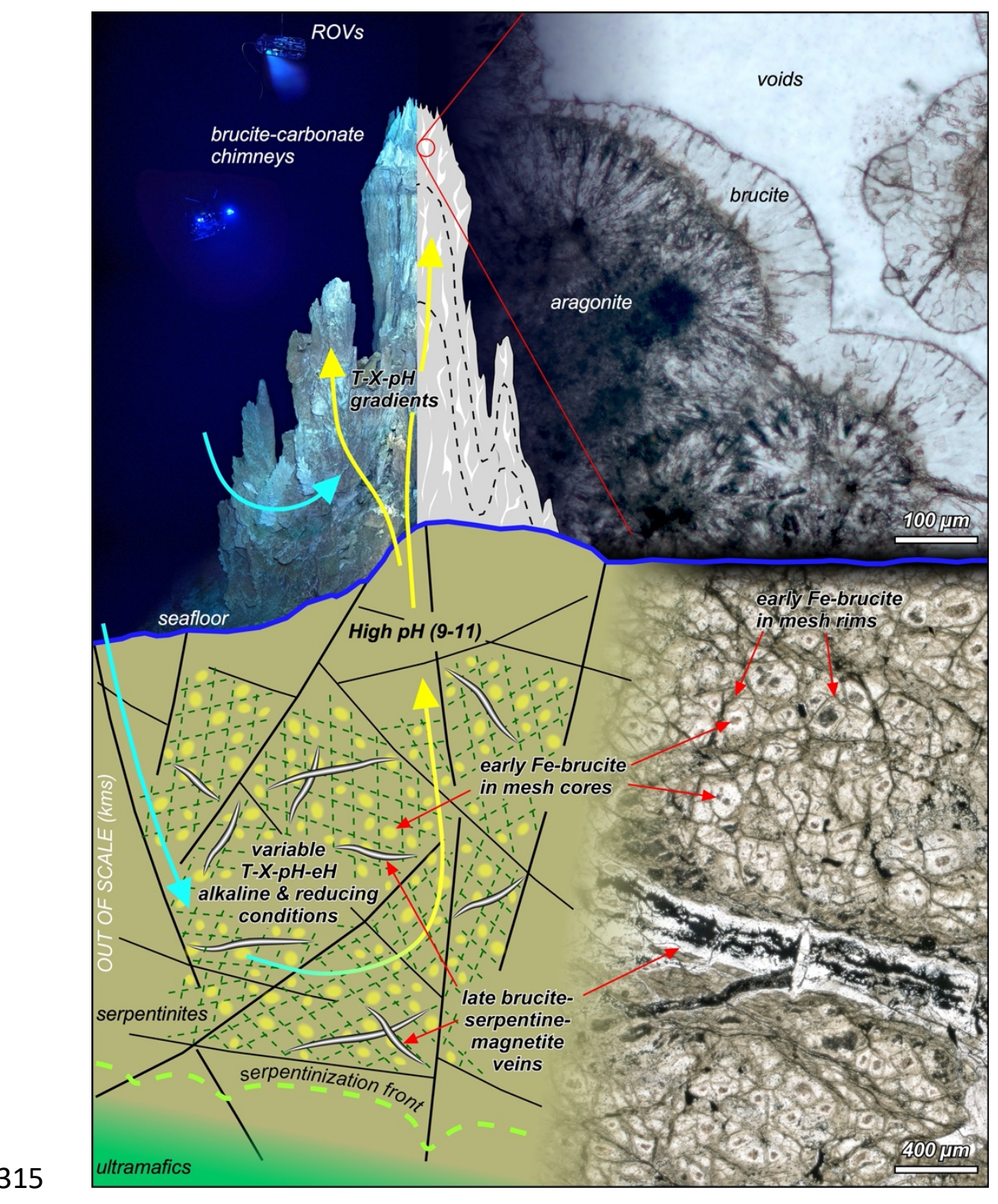

316 Figure 1: An idealised sketch of one of the hydrothermal systems that constituted the

317 global hydrothermal reactor in the Hadean-Archean. The sketch is based on samples and

318 geological evidence collected at the Lost City Hydrothermal Field. The widespread availability

319 of seawater-mantle interfaces in the early Earth triggered the diffusion of brucite in a large

320 variety of environments (subterranean, submarine and even subaerial) dominated by alkaline,

321 reduced conditions. The residual character of Hadean mantle rocks maximised the diffusion of

322 brucite, with its unique catalytic properties, providing an unrepeatable global scenario for

323 prebiotic synthesis. Lost City image courtesy of D. Kelley and M. Elend (University of

324 Washington). 


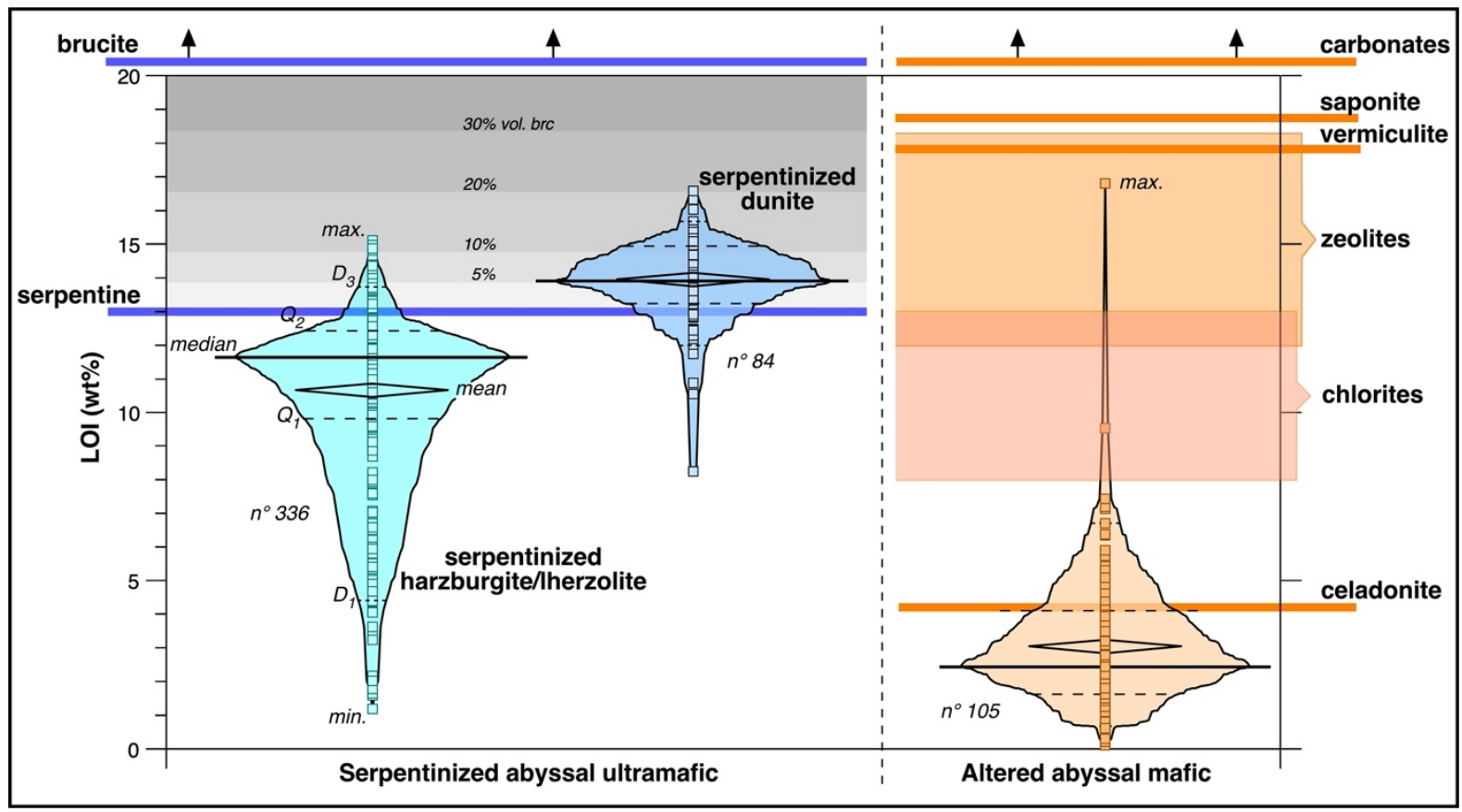

327 Figure 2: Box-percentile plots for abyssal serpentinized upper mantle rocks and altered basalts

328 showing a distinct degree of alteration (visualised by loss on ignition; LOI). Mean and median

329 of serpentinite LOI roughly overlap the LOI of serpentine minerals (with a variable brucite 330 content) indicating the extreme efficiency of the hydration process. On the contrary, the mean

331 and the median of altered basalt LOI are much lower than the LOI of the alteration assemblage

332 (smectites, chlorites, zeolites and celadonite) indicating a less efficient reaction process.

333 Furthermore, box-percentile plots for serpentinized lherzolite-harzburgite and dunites indicate

334 that olivine-dominated systems, characteristic of the residual Hadean-Archean mantle, produce

335 larger amounts of brucite. Data collected from Refs. ${ }^{30,32,34,35,55}$. 

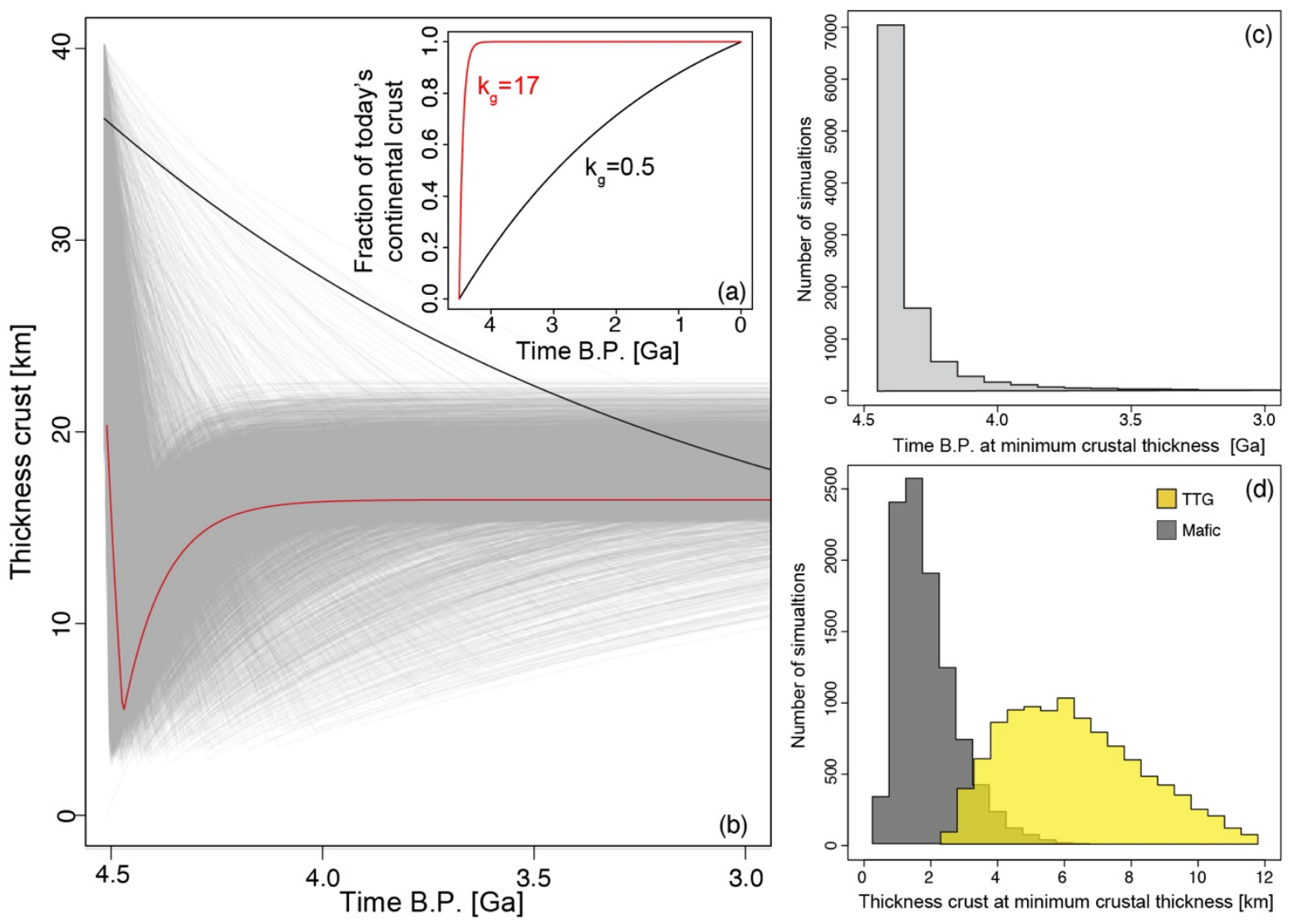

338 Figure 3: Results of the mass balance calculations. a) End members model for the evolution

339 of the mass of the continental crust in time. In the Monte Carlo simulations we randomly

340 sample between the two end member model shown by the red and black curve. b) Grey lines

341 show the evolution of the crust thickness (Hadean, continental and mafic produced by partial

342 melting of the mantle; Methods) in time. The black and red line are for two simulations

343 considering the two end-member growth scenarios presented in panel a. c) Distribution of times

344 at which the thickness of the crust reaches minimum values. c) distributions of the thickness of

345 mafic and TTG-type crust once the total crustal thickness is at its minimum. 